\title{
Organosilicon Polymer-Derived Bioceramics for Bone Tissue Engineering
}

Shengyang Fu and Yufang Zhu*

School of Materials Science and Engineering, University of Shanghai for Science and Technology, China

\section{Editorial}

Organosilicon polymer-derived ceramics strategy has emerged a number of advantages in fabricating bioceramics for bone tissue engineering [1,2]. In traditional, the fabrication processes of silicate bioceramics including preparation of raw materials, shaping, porosity making and sintering. However, solid state reaction, sol-gel as well as other common methods are either high-energy consumption or difficult in processing and shaping. Fortunately, organosilicon polymers have been synthesized for fabricating silicate bioceramics in recent decades. The fabrication of organosilicon polymer-derived bioceramics involves cross-linking, pyrolysis and ceramization. In order to obtain silicate bioceramics, active fillers are added and they can react with silicon during polymer pyrolysis. One of the most important advantages for polymer-derived silicate bioceramics strategy is the combination of shaping with synthesis and the dispersity of active filers in polymer solution, which is better than that in solid environment, resulting in a decrease of sintering temperature as well.

To date, a variety of silicate bioceramics including calcium-based silicates $\left(\mathrm{CaO} \cdot \mathrm{SiO}_{2}, 2 \mathrm{CaO} \cdot \mathrm{SiO}_{2}\right)$, forsterite $\left(2 \mathrm{MgO} \cdot \mathrm{SiO}_{2}\right)$, mullite $\left(3 \mathrm{Al}_{2} \mathrm{O}_{3} \cdot 2 \mathrm{SiO}_{2}\right)$, zircon $\left(\mathrm{ZrO}_{2} \cdot \mathrm{SiO}_{2}\right)$, willemite $\left(2 \mathrm{ZnO} \cdot \mathrm{SiO}_{2}\right)$, and ternary silicates such as akermanite (2CaO $\left.\cdot \mathrm{MgO} \cdot 2 \mathrm{SiO}_{2}\right)$, diopside $\left(\mathrm{CaO} \cdot \mathrm{MgO} \cdot 2 \mathrm{SiO}_{2}\right)$, hardystonite $\left(2 \mathrm{CaO} \cdot \mathrm{ZnO} \cdot 2 \mathrm{SiO}_{2}\right)$, gehlenite $\left(2 \mathrm{CaO} \cdot \mathrm{Al}_{2} \mathrm{O}_{3} \cdot \mathrm{SiO}_{2}\right)$, cordierite $\left(2 \mathrm{MgO} \cdot 2 \mathrm{Al}_{2} \mathrm{O}_{3} \cdot 5 \mathrm{SiO}_{2}\right)$ have been successfully fabricated via polymer-derived strategy. As known, most of silicate bioceramics have been developed for bone tissue engineering due to their outstanding bioactivity [3].

As the commonest silicate bioceramics, wollastonite $\left(\mathrm{CaSiO}_{3}\right)$ was first fabricated via the polymer-derived strategy by Bernardo et al. [4,5]. Different organosilicon polymers and calcium sources such as $\mathrm{CaCO}_{3}$, $\mathrm{Ca}(\mathrm{OH})_{2}, \mathrm{CaO}$ were used, and wollastonite could be synthesized beyond $1000^{\circ} \mathrm{C}$. The crystallinity of wollastonite was influenced by the particle size of calcium sources, and the smaller sized active fillers with higher surface area led to a better crystallinity. Similarly, $\beta-\mathrm{Ca}_{2} \mathrm{SiO}_{4}$ could be fabricated from silicone resin loaded with $\mathrm{CaCO}_{3}$ active fillers [1]. $\beta-\mathrm{Ca}_{2} \mathrm{SiO}_{4}$ phase could be formed over $900^{\circ} \mathrm{C}$ sintering and the crystallinity of the ceramic scaffolds increased with increasing the sintering temperature. Furthermore, ternary silicates such as hardstonite $\left(\mathrm{Ca}_{2} \mathrm{ZnSi}_{2} \mathrm{O}_{7}\right)$ [6,7] and akermanite $\left(\mathrm{Ca}_{2} \mathrm{MgSi}_{2} \mathrm{O}_{7}\right)$ [8] were also fabricated from the same organosilicon polymers loaded with $\mathrm{CaCO}_{3}$ active fillers, in which $\mathrm{ZnO}$ and $\mathrm{Mg}(\mathrm{OH})_{2}$ acted as second active fillers, respectively. Fiocco et al. [9] fabricated bioactive glasses (BG) derived from organosilicon polymers and active fillers. By adjusting the proportion such as $\mathrm{CaCO}_{3}, \mathrm{Na}_{2} \mathrm{CO}_{3}$ and $\mathrm{Na}_{2} \mathrm{HPO}_{4} \cdot 7 \mathrm{H}_{2} \mathrm{O}, 45 \mathrm{~S} 5$ and $58 \mathrm{~S}$ bioactive glasses were fabricated from the reaction between silica and active fillers at $1000^{\circ} \mathrm{C}$. Therefore, most of silicate bioceramics can be fabricated via polymer-derived strategy from organosilicon polymers loaded with different active fillers in a specific ratio.

Based on these studies, there are many researches about silicate composites derived from polymers. Hydroxyapatite (HA) is a naturally mineral form of calcium phosphate and bioactive glass (BG) are bioactive in vivo for bone regeneration, which have been widely used for improving the biological property $[10,11]$. For example, wollastonite/ hydroxyapatite and wollastonite/AP40 BG composites have been fabricated from organosilicon polymer loaded with $\mathrm{CaCO}_{3}$ active fillers, while hydroxyapatite and bioactive glass were as passive fillers [12,13]. Besides improving biological properties, the passive fillers can provide a smaller shrinkage during ceramization. Elsayed et al. and Fiocco et al. [14-17] fabricated wollastonite/diopside composite with a molar ratio of 1:1. $\mathrm{CaCO}_{3}$ and $\mathrm{Mg}(\mathrm{OH})_{2}$ were used as both active fillers and reacted with organosilicon polymers at $1100^{\circ} \mathrm{C}$ to form wollastonite and diopside phases.

Except for component, porosity is another vital factor for bioceramics, which facilitates cell attachment, migration as well as flow transport of nutrients and bone ingrowth. The addition of foaming agents in starting materials is a common method to fabricate porous silicate bioceramics. Common foaming agents include polyurethane (PU), borax $\left(\mathrm{Na}_{2} \mathrm{~B}_{4} \mathrm{O}_{7} \cdot 10 \mathrm{H}_{2} \mathrm{O}\right)$, sodium borate, sodium phosphate dibasic heptahydrate $\left(\mathrm{Na}_{2} \mathrm{HPO}_{4} \cdot 7 \mathrm{H}_{2} \mathrm{O}\right)$, dicarbamoylhydrazine $(\mathrm{DCH})$, polymethyl methacrylate (PMMA), Pluronic P123, etc [18]. However, residual foams or impurities may damage the silicate bioceramics, and these traditional methods cannot provide a well pore interconnection, proper pore size or high porosity. In recent years, 3D printing has been developed and is able to create a complex porous structure for polymerderived silicate bioceramics $[19,20]$.

The process of fabricating organosilicon polymer-derived silicate bioceramics is easily combined with $3 \mathrm{D}$ printing due to the regulated rheological property of polymers. Direct ink writing was first employed to shape organosilicon polymers to obtain wollastonite. A printable paste was prepared firstly by mixing $\mathrm{CaCO}_{3}$ into polymer solution for $3 \mathrm{D}$ printing, and then the wollastonite was obtained after a sintering process. Porous hardystonite $\left(\mathrm{Ca}_{2} \mathrm{ZnSi}_{2} \mathrm{O}_{7}\right)$ were fabricated by direct ink writing by Zocca et al. [6]. $\mathrm{ZnO}$ and $\mathrm{CaCO}_{3}$ powders were mixed into organosilicon polymer solution to form a printable ink. The final hardstonite scaffolds possesses large porosity $(>76 \%)$ with a compressive strength of ca. $2.5 \mathrm{MPa}$. Similarly, wollastonite/diopside composite scaffolds were successfully fabricated by the same method, and the obtained scaffold possesses large porosity $(68 \%-76 \%)$ with a compressive strength (3.9-4.9 MPa). On the other hand, Zocca et al. [12] fabricated wollastonite/AP40 BG scaffolds by powder-based 3D printing. Polysiloxane as an organosilicon polymer, $\mathrm{CaCO}_{3}$ and $\mathrm{AP} 40$ bioactive glass powders were used as each deposit layer $(150 \mu \mathrm{m})$. A mixture of 1-hexanol and hexylacetate was used as a printing liquid. After layer-by-layer shaping and sintering, the obtained composite

*Corresponding author: Yufang Zhu, School of Materials Science and Engineering, University of Shanghai for Science and Technology, 516 Jungong Road, Shanghai, 200093, China, Tel: 021-55271663; E-mail: zjf2412@163.com

Received September 14, 2018; Accepted September 17, 2018; Published September 20, 2018

Citation: Fu S, Zhu Y (2018) Organosilicon Polymer-Derived Bioceramics for Bone Tissue Engineering. J Bioanal Biomed 10: e157. doi:10.4172/1948-593X.1000e157

Copyright: @2018 Fu S, et al. This is an open-access article distributed under the terms of the Creative Commons Attribution License, which permits unrestricted use, distribution, and reproduction in any medium, provided the original author and source are credited. 
scaffolds possess a porosity of $80 \%$ and a biaxial flexural strength of ca. $6 \mathrm{MPa}$.

Subsequently, the biological property of silicate bioceramics is also important and many related studies on organosilicon polymer-derived silicate bioceramics. Human osteoblast and fibroblast cells have been used to evaluate the cell compatibility for those organosilicon polymerderived bioceramic scaffolds, which showed good bioactivity and the ability for cell adhesion, proliferation and differentiation.

In general, organosilicon polymer-derived bioceramics strategy has been developed for bone tissue engineering due to its low-energy consumption and easy for shaping. To fabricate the silicate bioceramics derived from organosilicon polymers, there are four main processes including the preparation of raw materials, shaping, cross-linking and sintering. Different organosilicon polymers and fillers decide the final component of bioceramics. However, there is no denying that the shrinkage and cracks of the organosilicon polymer-derived silicate bioceramics cannot be controlled precisely. Combining with $3 \mathrm{D}$ printing technique, the obtained silicate bioceramics are more suitable for application in bone tissue engineering. In future, the development of organosilicon polymers can fabricate other functional bioceramics, such as borate and phosphate ceramics, and 3D printing provides bioceramics with promising porous structures for bone tissue engineering.

\section{Acknowledgement}

The authors gratefully acknowledge the support by grants from the National Natural Science Foundation of China (No. 51872185) and the Science and Technology Commission of Shanghai Municipality (No. 17060502400).

\section{References}

1. Fu S, Liu W, Liu S, Zhao S, Zhu Y (2018) 3D printed porous $\beta$-Ca2SiO4 scaffolds derived from preceramic resin and their physicochemical and biological properties. Sci Technol Adv Mater 19: 495-506.

2. Colombo P, Mera G, Riedel R, Sorarù GD (2010) Polymer-derived ceramics: 40 years of research and innovation in advanced ceramics. J Am Ceram Soc 93: 1805-1837.

3. Wu CT, Chang J (2013) Bioceramics for bone tissue regeneration. J Inorg Mater 28: 29-39.

4. Bernardo E, Colombo P, Dainese E, Luchetta G, Barani PF (2012) Novel 3D wollastonite-based scaffolds from preceramic polymers containing micro- and nano-sized reactive particles. Adv Eng Mater 14: 269-274.

5. Bernardo E, Parcianello G, Colombo P, Matthews S (2013) Wollastonite foams from an extruded preceramic polymer mixed with caco 3 microparticles assisted by supercritical carbon dioxide. Adv Eng Mater 15: 60-65.
6. Zocca A, Franchin G, Elsayed H, Gioffredi E, Bernardo P, et al. (2016) Direct ink writing of a preceramic polymer and fillers to produce hardystonite $\left(\mathrm{Ca}_{2} \mathrm{ZnSi}_{2} \mathrm{O}_{7}\right)$ bioceramic scaffolds. J Am Ceram Soc 99: 1960-1967.

7. Elsayed H, Zocca A, Franchin G, Bernardo E, Colombo P (2016) Hardystonite bioceramics from preceramic polymers. J Eur Ceram Soc 36: 829-835.

8. Bernardo E, Carlotti JF, Dias PM, Fiocco L, Colombo P (2014) Nove akermanite-based bioceramics from preceramic polymers and oxide fillers. Ceram Int 40: 1029-1035.

9. Fiocco L, Bernardo E, Colombo P, Cacciotti I, Bianco A, et al. (2014) Nove processing of bioglass ceramics from silicone resins containing micro- and nano-sized oxide particle fillers. J Biomed Mater Res A 102: 2502-2510.

10. So K, Fujibayashi S, Neo M, Anan Y, Ogawa T, et al. (2006) Accelerated degradation and improved bone-bonding ability of hydroxyapatite ceramics by the addition of glass. Biomaterials 27: 4738-4744.

11. Zhang J, Zhao S, Zhu M, Zhu Y, Zhang Y, et al. (2014) 3D-printed magnetic Fe304/MBG/PCL composite scaffolds with multifunctionality of bone regeneration, local anticancer drug delivery and hyperthermia. J Mater Chem B 2: 7583-7595.

12. Zocca A, Elsayed H, Bernardo E, Gomes CM, Lopez-Heredia MA, et al. (2015) 3D-printed silicate porous bioceramics using a non-sacrificial preceramic polymer binder. Biofabrication 7: 025008.

13. Fiocco L, Li S, Bernardo E, Stevens MM, Jones JR (2016) Highly porous polymer-derived wollastonite-hydroxycarbonate apatite ceramics for bone regeneration. Biomed Mater 11: 025016.

14. Fiocco L, Elsayed H, Dagunano JKMF, Soares VO, Beranrdo E (2015) Silicone resins mixed with active oxide fillers and $\mathrm{Ca}-\mathrm{Mg}$ silicate glass as alternative/ integrative precursors for wollastonite-diopside glass-ceramic foams. J NonCryst Solids 416: 44-49.

15. Elsayed H, Colombo P, Bernardo E (2017) Direct ink writing of wollastonitediopside glass-ceramic scaffolds from a silicone resin and engineered fillers. J Eur Ceram Soc 37: 4187-4195.

16. Fiocco L, Ferroni L, Gardin C, Zavan B, Secco M, et al. (2016) Wollastonitediopside glass-ceramic foams from supercritical carbon dioxide-assisted extrusion of a silicone resin and inorganic fillers. J Non-Cryst Solids 443: 33-38.

17. Fiocco L, Elsayed H, Ferroni L, Gardin C, Zavan B, et al. (2015) Bioactive Wollastonite-Diopside Foams from Preceramic Polymers and Reactive Oxide Fillers. Materials 8: 2480-2494.

18. Pei P, Qi X, Du X, Zhu M, Zhao S, et al. (2016) Three-dimensional printing of tricalcium silicate/mesoporous bioactive glass cement scaffolds for bone regeneration. J Mater Chem B 4: 7452-7463.

19. Ma H, Feng C, Chang J, Wu C (2018) 3D-printed bioceramic scaffolds: From bone tissue engineering to tumor therapy. Acta Biomater.

20. Du X, Fu S, Zhu Y (2018) 3D printing of ceramic-based scaffolds for bone tissue engineering: an overview. J Mater Chem B 6: 4397-4412. 